\title{
On the variation of the needle, as observed during a voyage to and from India
}

\section{W. H. White H.M.C.S.}

To cite this article: W. H. White H.M.C.S. (1829) On the variation of the needle, as observed during a voyage to and from India, Philosophical Magazine Series 2, 6:32, 153-153, DOI: $10.1080 / 14786442908675108$

To link to this article: http://dx.doi.org/10.1080/14786442908675108

里 Published online: 14 Jul 2009.

Submit your article to this journal $[\pi$

Џlll Article views: 1

Q View related articles $๘$ 
ON THE VARIATION OF THE NEEDLF, AS OBSERVED DURING

A VOYAGE TO AND FROM INDIA. BY W. H. WHITE, H.M.C.S.

To the Editors of the Philosophical Magazine and Annals.

Gentlemen,

Not having seen any thing lately on the variation of the mariner's compass, and having just perused the private $\log$ of a gentleman recently returned from India, I have extracted a few observations, showing the variation at four nearly corresponding latitudes, outward and inward.

\begin{tabular}{|c|c|c|}
\hline \multicolumn{3}{|c|}{ Outward bound. } \\
\hline Latitude. & Iongitude. & Variation. \\
\hline $49^{\circ} 30^{\prime} \mathrm{N}$ & $5^{\circ} 30^{\prime} \mathrm{W}$ & $27^{\circ} \mathrm{W}$ \\
\hline $10 \mathrm{~S}$ & $2330 \mathrm{~W}$ & $10 \mathrm{~W}$ \\
\hline $2100 \mathrm{~S}$ & $3700 \mathrm{~W}$. & 00 \\
\hline $4000 \mathrm{~S}$ & $3100 \mathrm{E}$. & $31 \mathrm{~W}$. \\
\hline \multicolumn{3}{|c|}{ Homeward bound. } \\
\hline $\begin{array}{l}\text { Latitude. } \\
36^{\circ} 30^{\prime} \mathrm{S} \text {. }\end{array}$ & $\begin{array}{l}\text { Longitude. } \\
23^{\circ} 00^{\prime} \mathbf{E} .\end{array}$ & $\begin{array}{l}\text { Variation. } \\
28^{\circ} \mathrm{W} \text {. }\end{array}$ \\
\hline $2130 \mathrm{~S}$ & $251 \mathrm{E}$. & $20 \mathrm{~W}$ \\
\hline $20 \mathrm{~N}$. & $1825 \mathrm{~W}$. & W. \\
\hline $4940 \mathrm{~N}$. & $540 \mathrm{~W}$ & $25 \mathrm{~W}$ \\
\hline
\end{tabular}

In the outward passage, it appears that the variation diminished as the latitude diminished and the longitude increased westward, till the ship reached latitude $21^{\circ} \mathrm{S}$., longitude $37^{\circ} \mathrm{W}$, when it entirely ceased. A progressive increase again took place as the ship continued to sail southward, making $\mathbf{E}$. longitude.

In the homeward passage there is a regular diminution of variation as the ship sails westward; and as a proof that the compass is not influenced by latitude, at least in the torrid zone, we find in latitude $21^{\circ} 30^{\prime} \mathrm{S}$. the variation was $20^{\circ} \mathrm{W}$., whereas in $21^{\circ} \mathrm{S}$. in the outward passage, having a difference of $39^{\circ} 51^{\prime} \mathrm{W}$. longitude, there was no variation. Hence it appears as the ship increases in $E$. longitude from $37^{\circ} \mathrm{W}$, the variation of the compass increases W., but to what extent I believe is not determined.

Should these observations be worthy of insertion in your scientific Journal, they may lead to a completion of facts that would highly benefit the science of navigation.

I am, Gentlemen, yours, \&c.

Bedford, July 8, 1829. W. H. WhITE, H.M.C.S.

\section{ACIIVE MOLECULES IN ORGANIC AND INORGANIC BODIES.}

The peculiar and apparently inherent motion of these molecules discovered some time since by R. Brown, Esq. F.R.S.,* excites an increased interest in consequence of the difficulty of accounting for it satisfactorily. Mr. Holland, who has for some time closely applied himself to microscopic researches, has found that the motion continues equally vivid, when the liquid containing the molecules

* See Phil. Mag. and Annals, N.S. vol. iv. p. 161.

N. S. Vol. 6. No. 32. Aug. 1829. 